\title{
Development of Flipbook using Web Learning to Improve Logical Thinking Ability in Logic Gate
}

\author{
Rizki Noor Prasetyono ${ }^{1}$, Rito Cipta Sigitta Hariyono ${ }^{2}$ \\ Faculty of Science and Technology \\ University of Peradaban \\ Brebes, Jawa Tengah \\ Indonesia
}

\begin{abstract}
The multimedia-based learning process has great potential to change the way of learning. One of them is a growing multimedia Flipbook from textbooks, with ease of reading and learning without carrying a thick book. The purpose of this study is to produce a Flipbook-assisted Web Learning development product and to improve the ability to logical thinking by using those products. This type of research using the 4D Models model consisting of define, design, develop, and disseminate. The results of the development with expert data validation analysis obtained an overall percentage of $83.92 \%$ included in the excellent category. Analysis of the validation of media expert's overall percentage obtained $80 \%$ included in the excellent category. And the validation analysis of peers the overall percentage found $84.78 \%$ included in the excellent category. From all analysis shows that flipbook-assisted teaching materials web learning is appropriate to be used. The results of the t-test calculations show 10.25 higher than 2.045, the use of flipbook logic gates assisted with web learning increases the ability of logical thinking. And the analysis of $\mathrm{N}$-Gain $\mathbf{0 . 3 9}$ in including the medium criteria, the flipbook gate logic assisted with web learning to increase the ability to logical thinking.
\end{abstract}

Keywords-Multimedia based learning; flipbook; web learning; logical thinking; logic gates

\section{INTRODUCTION}

The development of information and communication technology is a concern in all countries. The internet has penetrated the community, even education is outdated if it is not integrated with the internet. The Indonesian government supports through the Minister of Education and Culture Regulation No. 24 of 2012 which is about distance education (PJJ) organized by tertiary education. And approved by Law No. 12 of 2012 concerning higher education specifically in article 31 paragraph 2, approving the implementation of distance education to collect and examine arrangements in education and learning in Higher Education. This shows the importance of online-based learning in discussion and learning in higher education. With online-based learning, students can plan learning time and complete material better.

The multimedia-based learning process has great potential to change the way of learning. Multimedia modules or textbooks become a guide in learning, in accordance with the research of Abu Bakar et al the modules which have visual and graphic elements are very suitable in learning and have the feasibility to be used [1]. One of them is Flipbook, multimedia that developed from textbooks with ease of reading and learning without carrying thick books. In Sugianto's research [2] the virtual module based on Flipbook has an impact on improving learning outcomes, especially in learning digital basics. Arai's research also mentioned that e-learning is capable and effective in learning, especially learning complex formulas [3]. This shows that the use of media is important in learning based on some of this research.

Logic gate becomes material that must be understood by informatics engineering students. Where ordinary algebraic understanding cannot be applied in logic gate material. It takes time and understanding to be accepted by logic. According to Halim [4], the basic material for logic gates is needed by media which helps to facilitate further understanding. As in the study of Ash-Shiddieqy et al stated that the right media can provide effectiveness in improving logical thinking [5]. according to the research, G. Deena and D. K. Raja also state that it takes media such as E-learning because it is a very flexible time and space in learning [6].

From the observation of informatics engineering students at the University of Peradaban 6th semester of the academic year 2017/2018 who have taken digital courses. Students who understand logic gate material is not more than $50 \%$ and the difficulty faced is the lack of learning meeting time and teaching materials that still cannot be understood without teaching. This refers to the need for effective learning outside the classroom that is able to provide understanding and time that adjusts from the support of the Indonesian government through the rule of law regarding multimedia and internetbased learning. Refer also from previous research regarding the importance of technology-based learning, both in terms of multimedia and internet-based learning. Reinforced by the results of observations resulted that some students did not understand the logic gate material. This shows that it is needed learning media that are able to provide a flexible alternative in learning that is by developing Flipbook Learning aided Web Learning on logic gate materials to improve the ability of logical thinking.

The limitation of the research is the material that focuses on logic gates because it is related to students' ability to think logically. Another disadvantage is that flipbooks require a computer, smartphone, and internet connection to use. If there is none, then learning/lecture is difficult. Then this study aims only to find out the increase in the use of logic gate material flipbooks to improve logical thinking skills. 


\section{LITERATURE REVIEW}

\section{A. E-Learning}

Technological development is a benchmark for change in everything. Industry, society, and even education take part in the effects of technological development. Technology is very influential, one of which is learning media; Indonesian government through Government Regulation No. The year 2005 contains in the organization of education units must be held interactively, inspiring, fun, creative, motivating students, initiatives, channeling talents, interests, supported by physical as well as students who are processed in learning. The explanation provides the view that innovation in developing textbooks is a necessity to support learning.

Electronic Learning (E-Learning) is no longer a common thing in learning innovation under technological developments. There are many types of e-learning that can be used, one of them is E-Book. According to the research Salem et al, elearning proved beneficial, in that students can gain knowledge or information with a low cost of education and students can learn in all times and places [7]. According to Korat et al that the eBook has the advantage of software-based multimedia that can be used in a proper electronic device [8]. Making E-Books in technological developments now many applications that can be used such as Microsoft Office, Macromedia Flash, Adobe Reader PDF, and Flipbook Maker. Flipbook Maker: The application can be used to make the E-Book look more attractive, simple and easy to use.

Flipbook Maker is a textbook application in the form of files to make it more interesting. According to Hidayatullah Flipbook Maker helps students read directly to feel like opening a book with interesting animation effects [9]. Mulyadi $\&$ Wahyuni also stated that the use of Flipbook in the medium of learning to improve students' creative thinking [10]. Also supported by Biological research is the use of Flipbook learning media that can also improve student learning outcomes in physics [11]. So learning integrated with technology through Flipbook provides benefits for students in the learning process.

\section{B. Logical Thinking}

Scientific thinking in learning in higher education becomes a necessity in terms of knowledge and skills in order to be growing. Logical thinking is one of the scientific thoughts that must be possessed. Logical thinking cannot be separated from reality, where thinking is the result of the product of reality in the form of the laws of reality which become rules of thinking [12]. For example, in thinking someone adding up the numbers 1 and 1 will produce the number 2 , then this is supported by the reality and reality of the facts that can be proven. Heryadi states etymologically logic is a science of reasoning or reasoning that makes the law of thought acceptable [13]. So it can be concluded logical thinking rules of thought that can be accepted by reason and proven by facts.

According to Suryabrata, Logical thinking, in essence, goes through three stages [14]. First the construction of understanding, human thought is based on understanding a concept and then building the main contents in thinking. Second, opinion construction arises where the understanding that has been formed is supported by connecting the existing theoretical concepts and observing objects or events so that it becomes a logical process. And lastly, a Construction conclusion is drawn from an opinion that evaluated the existing concept of knowledge into new knowledge. This process is taken into consideration or decision making to be the correct reasoning process.

Logical thinking is very useful in achieving the learning objectives that have been made. As in Yani et al., all research [15] developments in logical thinking play a role in the achievement of learning objectives, especially in science experiments. Even in research Fadiana et al used a logical thinking ability test to find out the students' initial ability to make learning plans [16]. Supported by Othman et al [17] that logical thinking can be used to analyze the way of learning of students who have low cognitive levels combined with students who think high cognitive.. Some of these studies show the importance of increasing students to improve the ability to logical thinking in their application.

\section{METHOD}

\section{A. Research Methods}

This research was conducted to create learning media with a flipbook. Then validated by material experts, media experts, and peer reviews. The product developed in the form of a flipbook was then tested on Peradaban University students to find an increase in logical thinking skills. To develop a product used by the 4D model development research. Where the 4D Model process consists of define, design, develop, and disseminate.

\section{B. Define}

This stage of the process is carried out planning needs in developing products. With the stages of the study of literature from several reference theories in accordance with product development. Field studies are observing students about the difficulties encountered in lectures.

\section{Design}

This stage goes through several processes consisting of:

- Looking for material reference: The determination of references for the material is needed to provide guidelines or references in the basic theory and context of the product to be developed.

- Preparation of teaching material: This process is carried out in the preparation of the contents of the development product based on several references.

- Preparation of electronic-based textbooks: This process is an advanced stage in the form of a rough form of electronic textbooks, determining the teaching material to be developed is able to provide an interest

- Design: This process emerges the initial product design which will be carried out to the development stage and validated 


\section{Development}

The development phase is carried out in several stages, namely as follows:

- Development Stage: the draft that has been made then drafted the book product in a format suitable for the device to be used in the form. Flipbooks compiled in the making of designs are made to suit the use of Web Learning. The contents of the material are arranged to develop logical thinking skills.

- Expert Validation Stage: the aim of expert validation is to produce revised product drafts based on expert input. After the draft-1 is validated, the next step is to revise draft-1 so that it produces draft-2.

- Small-scale Trial: draft-2 revised draft-1 then a smallscale trial is conducted. For small scale trials that can be done with a Forum Group Discussion (FGD). This trial was conducted to obtain input and suggestions for improvement as well as assessment. The results of this small-scale trial will be used to revise the initial product to produce draft-3.

- Field Trials: draft-3 is then conducted field trials or large-scale trials, the purpose of this stage is to test the feasibility of the product.

\section{E. Disseminate}

This stage is the stage of using Web Learning-assisted Flipbook on logic gate material to measure the increase in logical thinking skills.

\section{F. Population and Research Sample}

The population for the selection is 6th-semester students (even) with a total of 30 students or one class. The sampling technique used is "saturated sample" meaning that the entire population that has been determined is used as a research sample. This is because the total population of 6th-semester students is relatively smaller.

\section{G. Product Validity Analysis}

The method of collecting product validity data uses a questionnaire, containing statements addressed to material experts, media experts, and peer reviews. Analysis of product data using a Likert scale questionnaire with a score of 1 to 4, with the rating category (4) very good, (3) good, (2) Poor, (1) very poor. Material experts observe and validate products on the aspect of content, aspects of material accuracy, stimulate curiosity, presentation and use of web learning on a flipbook. Media experts have validated the aspects of presentation, general appearance, language and readability, and the use of web learning on a flipbook. For peer review covering all aspects because they are practitioners in teaching.

TABLE. I. QuANTITATIVE SCORE RANGE FOR EACH CATEGORY

\begin{tabular}{|l|c|l|}
\hline No. & Quantitative Score Range & Category \\
\hline 1 & $\bar{X}>(M+1.5 \mathrm{Si})$ & Very Good \\
\hline 2 & $M<\bar{X} \leq(M+1.5 \mathrm{Si})$ & Good \\
\hline 3 & $(M-1.5 \mathrm{Si})<\bar{X} \leq M$ & Poor \\
\hline 4 & $\bar{X} \leq(M-1.5 \mathrm{Si})$ & Very Poor \\
\hline
\end{tabular}

The results of the validation questionnaire are then analyzed with a range of categories according to Table I.

For the value $\bar{X}$ is the average of the scores for each category of validators. $M$ is the median of each category score. then $S i$ is the standard deviation of each score.

Analysis of the ideal percentage of flipbook products using web learning with equation 1.

Percentage $(\%)=\frac{\text { total validation score }}{\text { maximum score }} \times 100 \%$

\section{H. Analysis of Increased Logical Thinking Ability}

The analysis compares the conditions before and after the field test so that the hypothesis is comparative using the t-test for two groups of data from one pair of sample groups as follows:

$t=\frac{M_{d}}{\sqrt{\frac{\sum X_{d}^{2}}{n(n-1)}}}$

Hypothesis for t-test from Eq. 1 for two data groups from one paired sample group namely:

$\mathrm{H}_{0}=$ There is no difference in mean values

$\mathrm{H}_{\mathrm{a}}=$ There is a difference in the mean value

Analysis to test the improvement of logical thinking skills is by:

gain $=\frac{\text { skor post tes }- \text { skor pretes }}{\text { Skor maximum-skor pretes }}$

The gain criteria are as follows:

Height: $g \geq 0.7$

Medium : $0.7>\mathrm{g} \geq 0.3$

Low $\quad: \mathrm{g}<0.3$

\section{DATA ANALYSIS}

Data analysis performed is product validity and analysis of logical thinking improvement. Data validity analysis of experts using the and analysis of logical thinking improvement Microsoft Excel application, which has been set up for calculating the validity and conclusion of its category.

Analysis of the validity of the material experts from the overall score criteria is in Table II. An analysis of the recap of overall validity by media experts according to Table III then for the overall analysis of data from the peer review according to Table IV.

Validity analysis by material experts containing 14 assessment criteria aimed at practitioners of logic gate material. The questionnaire which contains 14 criteria has 2 aspects of content, 2 aspects of material accuracy, 3 aspects of stimulating curiosity, 2 aspects of presentation, and 5 aspects of the use of web learning. The analysis also shows that each of these aspects has a very good category can be seen in Table VI.

The media experts in accordance with Table III show that they have 18 validity assessment criteria, which refer to learning media practitioners. where each aspect is 5 aspects of 
presentation, 5 aspects of general appearance, 3 aspects of language and readability, and 5 aspects of the use of web learning.

TABLE. II. ANALYSIS OF SCORE VALIDITY MATERIAL EXPERTS

\begin{tabular}{|c|c|c|c|c|c|c|}
\hline \multicolumn{2}{|c|}{ Overall Validity Score } & \multirow{3}{*}{\begin{tabular}{|l|} 
No \\
1
\end{tabular}} & & & & \multirow{3}{*}{$\begin{array}{l}\text { Category } \\
\text { Very Good } \\
\end{array}$} \\
\hline \multirow{2}{*}{$\begin{array}{l}\text { Total criteria } \\
\text { Maximum score } \\
\end{array}$} & \multirow{2}{*}{$\begin{array}{l}14 \\
56 \\
\end{array}$} & & \multicolumn{3}{|c|}{ Range Score } & \\
\hline & & & & $X>$ & 45.5 & \\
\hline Minimum score & 14 & 2 & 35 & $<X \leq$ & 45.5 & Good \\
\hline M & 35 & 3 & 24.5 & $<X \leq$ & 35 & Poor \\
\hline $\mathrm{Sb}$ & 7 & 4 & & $X \leq$ & 24.5 & Very Poor \\
\hline Average Score $(X)$ & 47 & & & & & \\
\hline \multicolumn{7}{|c|}{ Conclusion: } \\
\hline \multicolumn{6}{|c|}{$\begin{array}{l}\text { From the results of the analysis of the validation of the } \\
\text { material experts, it was found that flipbook assisted by web } \\
\text { learning was included in the category }\end{array}$} & Very Good \\
\hline
\end{tabular}

TABLE. III. ANALYSIS OF SCORE VALIDITY MEDIA EXPERT

\begin{tabular}{|c|c|c|c|c|c|c|}
\hline \multicolumn{2}{|c|}{ Overall Validity Score } & \multirow[b]{2}{*}{ No } & & & & \multirow{3}{*}{$\begin{array}{l}\text { Category } \\
\text { Very } \\
\text { Good }\end{array}$} \\
\hline Total criteria & 18 & & \multicolumn{3}{|c|}{ Range Score } & \\
\hline Maximum score & 72 & 1 & & $X>$ & 58.5 & \\
\hline Minimum score & 18 & 2 & 45 & $<X \leq$ & 58.5 & Good \\
\hline $\mathrm{M}$ & 45 & 3 & 31.5 & $<X \leq$ & 45 & Poor \\
\hline $\mathrm{Sb}$ & 9 & 4 & & $X \leq$ & 31.5 & Very Poor \\
\hline Average Score $(X)$ & 62 & & & & & \\
\hline \multicolumn{7}{|l|}{ Conclusion: } \\
\hline \multicolumn{6}{|c|}{$\begin{array}{l}\text { From the results of the analysis of the validation of the } \\
\text { material experts, it was found that flipbook assisted by } \\
\text { web learning was included in the category }\end{array}$} & Very Good \\
\hline
\end{tabular}

The validity criteria in the peer review questionnaire are more than the others. The total overall assessment criteria in the peer review were 23 criteria, consisting of 2 aspects of content, 2 aspects of material accuracy, 3 aspects of stimulating curiosity, 5 aspects of presentation, 5 aspects of general appearance, 1 aspect of language and readability, and 5 aspects of the use of web learning.

Data analysis increased logical thinking according to Table V. Data were taken through the pre-test before the treatment and post-test after the use of a flipbook assisted with web learning. Table $\mathrm{V}$ shows the analysis of the t-test and $\mathrm{N}$ gain from the pretest and posttest data.

TABLE. IV. ANALysis of SCORE VALIDITy PEER REVIEWS

\begin{tabular}{|c|c|c|c|c|c|c|}
\hline \multicolumn{2}{|c|}{ Overall Validity Score } & \multirow{3}{*}{$\begin{array}{l}\text { No } \\
1\end{array}$} & & & & \multirow{3}{*}{\begin{tabular}{|l|} 
Category \\
Very Good
\end{tabular}} \\
\hline \multirow{2}{*}{\begin{tabular}{l|l} 
Total criteria \\
Maximum score \\
\end{tabular}} & \multirow{2}{*}{$\begin{array}{l}23 \\
92 \\
\end{array}$} & & \multicolumn{3}{|c|}{ Range Score } & \\
\hline & & & & $X>$ & 74.75 & \\
\hline Minimum score & 23 & 2 & 57.5 & $<X \leq$ & 74.75 & Good \\
\hline $\mathrm{M}$ & 57.5 & 3 & 40.3 & $<X \leq$ & 57.5 & Poor \\
\hline $\mathrm{Sb}$ & 12 & 4 & & $X \leq$ & 40.25 & Very Poor \\
\hline Average Score $(X)$ & 78 & & & & & \\
\hline \multicolumn{7}{|l|}{ Conclusion : } \\
\hline \multicolumn{6}{|c|}{$\begin{array}{l}\text { From the results of the analysis of the validation of the material } \\
\text { experts, it was found that flipbook assisted by web learning was } \\
\text { included in the category }\end{array}$} & Very Good \\
\hline
\end{tabular}

TABLE. V. DATA ANALYSIS T-TEST AND N Gain

\begin{tabular}{|c|c|c|c|c|c|c|}
\hline $\begin{array}{l}\text { SAMPL } \\
\text { E }\end{array}$ & $\begin{array}{l}\text { PRETE } \\
\text { S }\end{array}$ & $\begin{array}{l}\text { POSTE } \\
\text { S }\end{array}$ & $\begin{array}{l}\text { GAIN } \\
\text { (d) }\end{array}$ & Xd & $(\mathbf{X d})^{2}$ & $\begin{array}{l}\text { N } \\
\text { GAIN }\end{array}$ \\
\hline 1 & 32 & 64 & 32 & 11.2 & 125 & 0.47059 \\
\hline 2 & 44 & 64 & 20 & -0.8 & 0.64 & 0.35714 \\
\hline 3 & 64 & 65 & 1 & $\begin{array}{l}- \\
19.8\end{array}$ & 392 & 0.02778 \\
\hline 4 & 64 & 76 & 12 & -8.8 & 77.4 & 0.33333 \\
\hline 5 & 52 & 76 & 24 & 3.2 & 10.2 & 0.5 \\
\hline 6 & 48 & 75 & 27 & 6.2 & 38.4 & 0.51923 \\
\hline 7 & 68 & 56 & -12 & $\begin{array}{l}- \\
32.8\end{array}$ & 1076 & -0.375 \\
\hline 8 & 48 & 65 & 17 & -3.8 & 14.4 & 0.32692 \\
\hline 9 & 68 & 78 & 10 & $\begin{array}{l}- \\
10.8 \\
\end{array}$ & 117 & 0.3125 \\
\hline 10 & 64 & 77 & 13 & -7.8 & 60.8 & 0.36111 \\
\hline 11 & 48 & 75 & 27 & 6.2 & 38.4 & 0.51923 \\
\hline 12 & 36 & 56 & 20 & -0.8 & 0.64 & 0.3125 \\
\hline 13 & 52 & 67 & 15 & -5.8 & 33.6 & 0.3125 \\
\hline 14 & 68 & 80 & 12 & -8.8 & 77.4 & 0.375 \\
\hline 15 & 64 & 78 & 14 & -6.8 & 46.2 & 0.38889 \\
\hline 16 & 28 & 56 & 28 & 7.2 & 51.8 & 0.38889 \\
\hline 17 & 56 & 76 & 20 & -0.8 & 0.64 & 0.45455 \\
\hline 18 & 32 & 65 & 33 & 12.2 & 149 & 0.48529 \\
\hline 19 & 28 & 65 & 37 & 16.2 & 262 & 0.51389 \\
\hline 20 & 32 & 68 & 36 & 15.2 & 231 & 0.52941 \\
\hline 21 & 32 & 68 & 36 & 15.2 & 231 & 0.52941 \\
\hline 22 & 56 & 78 & 22 & 1.2 & 1.44 & 0.5 \\
\hline 23 & 48 & 67 & 19 & -1.8 & 3.24 & 0.36538 \\
\hline 24 & 56 & 86 & 30 & 9.2 & 84.6 & 0.68182 \\
\hline 25 & 48 & 67 & 19 & -1.8 & 3.24 & 0.36538 \\
\hline 26 & 36 & 67 & 31 & 10.2 & 104 & 0.48438 \\
\hline 27 & 36 & 68 & 32 & 11.2 & 125 & 0.5 \\
\hline 28 & 52 & 78 & 26 & 5.2 & 27 & 0.54167 \\
\hline 29 & 64 & 79 & 15 & -5.8 & 33.6 & 0.41667 \\
\hline 30 & 72 & 80 & 8 & $\begin{array}{l}- \\
12.8\end{array}$ & 164 & 0.28571 \\
\hline \multicolumn{3}{|c|}{ AVERAGE } & 20.8 & & & 0.39281 \\
\hline \multicolumn{5}{|l|}{ TOTAL } & 3581 & \\
\hline \multicolumn{5}{|c|}{ Standard deviation (S) } & 4.12 & \\
\hline & \multicolumn{2}{|c|}{$\mathrm{t}-\mathrm{COUNT}$} & \multicolumn{3}{|c|}{ t-TABLE } & \\
\hline & \multirow{2}{*}{\multicolumn{2}{|c|}{10.25257438}} & \multicolumn{2}{|c|}{$\mathrm{DK}=\mathrm{N}-1=29$} & $\begin{array}{l}\alpha=5 \\
\%\end{array}$ & \\
\hline & & & \multicolumn{3}{|l|}{2,045} & \\
\hline
\end{tabular}

\section{RESUlTS AND DisCUSSION}

Media plays a role in the learning process because it can represent abstract material that cannot sometimes require extra explanation [4]. The most common media is teaching the material as a learning guide. Teaching materials developed in 
the form of logic gate flipbooks have characteristics; there are guidelines for the use of teaching materials that have an explanation in the content of teaching materials. Teaching materials developed in the form of logic gate Flipbooks have characteristics, there are guidelines for the use of teaching materials according to Fig. 1 which has an explanation in the content of teaching materials.

Media including textbooks helps in the implementation of learning, especially in higher education because the learning process has a short time. The aspect of fulfilling the development of teaching materials is very important to get decent and valid results. Appearance, material, language, and technical aspects are included in the assessment so it needs to be assessed by practitioners [18].

In Fig. 2 each sub material has a series that students can try out through the livewire application. Train for psychomotor and cognitive activities to explore each material being taught. Research states that there is an influence in thinking patterns of critical thinking with interactive learning processes in the classroom.

The results of this research were tested for eligibility through product validity testing by material experts, media experts, and peers. The validity of the product is developed by measuring the quality of the product and the percentage of product ideals. The recapitulation of the validation test data analysis from material experts, media experts, and peers in each aspect is presented in the following Table VI.

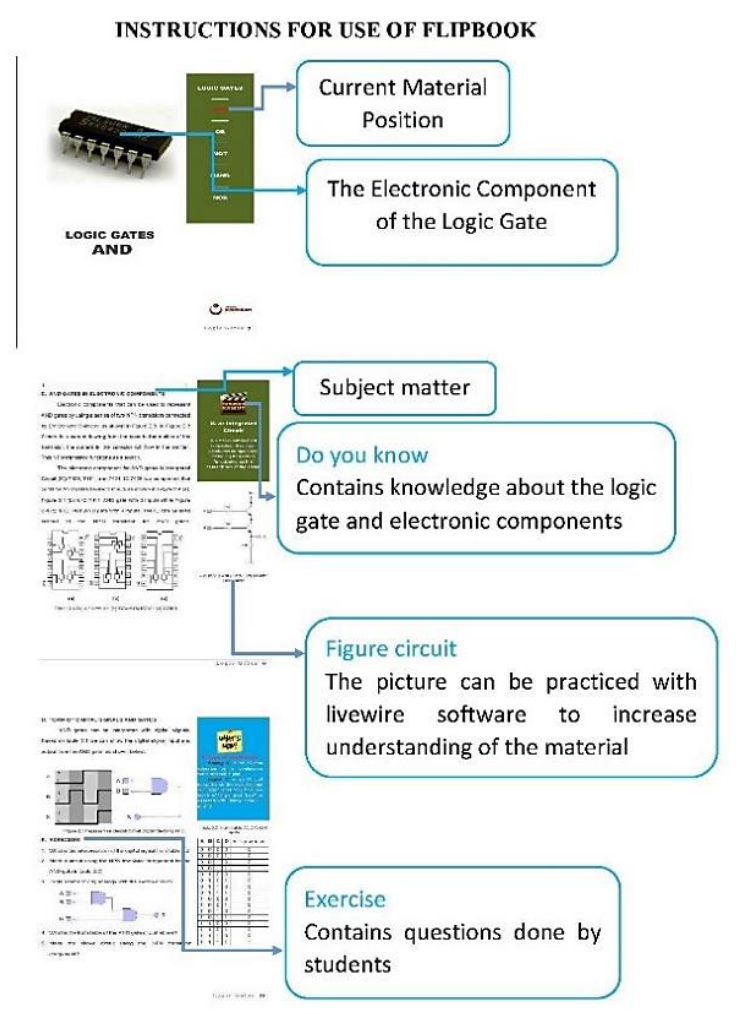

Logic Gates iii I

Fig. 1. Instructions for use of Teaching Materials.

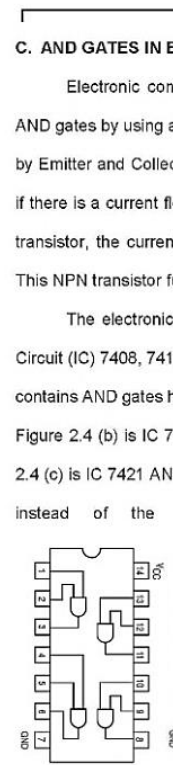

(a)
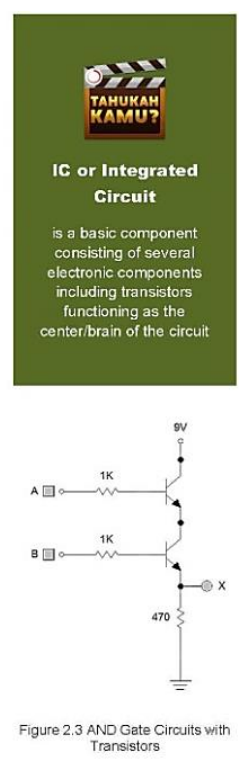

(c)

(b)

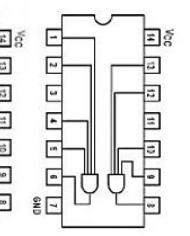

Fig. 2. Content of Flipbook Material.

TABLE. VI. RECAPITULATION OF VALIDATION ANALYSIS OF MATERIAL EXPERTS, MEDIA EXPERTS, AND PEER REVIEW FOR EACH ASPECT

\begin{tabular}{|l|c|l|l|l|l|l|}
\hline \multirow{2}{*}{ Aspect } & \multicolumn{2}{|l|}{ Material Expert } & \multicolumn{2}{l|}{ Media Expert } & \multicolumn{2}{l|}{ Peer Review } \\
\cline { 2 - 7 } & $\overline{\boldsymbol{X}}$ & Category & $\overline{\boldsymbol{X}}$ & Category & $\overline{\boldsymbol{X}}$ & Category \\
\hline $\begin{array}{l}\text { The content } \\
\text { aspect }\end{array}$ & 7 & Very good & & & 7 & Very good \\
\hline $\begin{array}{l}\text { Material } \\
\text { accuracy }\end{array}$ & 7 & Very good & & & 7 & Very good \\
\hline $\begin{array}{l}\text { Stimulate } \\
\text { curiosity }\end{array}$ & 10 & Very good & & & 10 & Very good \\
\hline Presentation & 7 & Very good & 16 & Good & 17 & Very good \\
\hline $\begin{array}{l}\text { The use of } \\
\text { web learning } \\
\text { in a flipbook }\end{array}$ & 16 & Good & 20 & Very good & 17 & Very good \\
\hline $\begin{array}{l}\text { General } \\
\text { appearance }\end{array}$ & & 17 & Very good & 16 & Good \\
\hline $\begin{array}{l}\text { Language / } \\
\text { Readability }\end{array}$ & & 9 & Good & 4 & Very good \\
\hline
\end{tabular}

Each expert is given a questionnaire that shows aspects according to their expertise and then analyzed to get the validity value of the product being tested. From the results of the data taken from the expert assessment material according to Table II, validation obtained an average score of 47 which according to the attachment of the score is included in the range $\bar{X}>45,5$ meaning in the very good category. Data taken from media experts according to Table III the results obtained an overall analysis of product validation obtained an average score of 62 which according to the attachment of the score is 
included in the range $\bar{X}>58,5$ meaning in the very good category [19]. Collecting data by peers reviews according to Table II validation of products obtained an average score is 78 wherein the score is included in the range of $\bar{X}>75$ means in the excellent category.

After analysis of the average score of validation data, then analyzed the percentage of ideals of the product. The percentage of product ideals by material experts that is $83.92 \%$ is included in the range of the percentage score $\bar{X}>81,25 \%$ in the very good category. Percentage of product ideals by media experts calculated according to overall aspect criteria is $80 \%$ included in the range of percentage $62,5 \%<\bar{X}<81,25 \%$ in the good category. The calculation of the overall percentage of product ideals for peers found $84.78 \%$ included in the range of score percentage $\bar{X}>81,25 \%$ in the very good category.

From the calculation results that have been presented both product quality analysis and percentage analysis of ideals, it is found that the flipbook gate logic web-assisted web learning products are in the very good category. The conclusion is that the product is feasible or valid to be tested and used. After product development and validity testing, it is then implemented in small groups. The first product trial was conducted at informatics engineering students for upper semester classes who already knew digital material. The trial was conducted 15 samples which obtained an average score of $81 \%$ included in the range $\bar{X}>81.25 \%$ meaning that in the good category. Recapitulation of student response data analysis in each aspect is presented in Table VII.

From Table VII shows that student responses from each aspect show that the average product is considered by the sample of users included good category. Then it can be concluded that from the data that the product was received then it could be continued for use to determine the effectiveness of the product. Further implementation to find out the increase and effectiveness of product use. In accordance with the analysis of the data shows that the use of flipbook gate logic assisted by web learning increases the ability of students to think logically by $20.8 \%$. Then from the results of t-test calculations for two groups of data from one paired sample group shows the value of $\mathrm{t}$-count 10.25 which means $\mathrm{t}$-count> t-table, where $10.25>2.045$ then $\mathrm{H}_{0}$ is rejected. It can be concluded that there is a difference in the average value between before and after using the flipbook gate logic assisted web learning, which shows that after the use of products the ability of logical thinking increases. In line with the research of Divayana et al [20] shows that in the development of flipbooks as a digital book design in both categories as a source of teaching.

Reinforced by the results of the N-GAIN analysis in accordance with Appendix 13, the pretest and posttest values had an N-Gain value of 0.39 which included in the range of $0.7>\mathrm{g} \geq 0.3$ moderate criteria. These results indicate that the flipbook gate logic is assisted by web learning to increase the ability of logical thinking to be effective and appropriate for use in the lecture process. Supported by research on the effectiveness of web-based learning support in the learning process because the process is easy and has unlimited access [21].
TABLE. VII. Percentage of Response Data For EACH AsPeCt

\begin{tabular}{|l|l|l|l|}
\hline No & Aspect & $\begin{array}{l}\text { Percentage of the } \\
\text { ideal score }(\%)\end{array}$ & Category \\
\hline 1 & Stimulate curiosity & 80,83 & Good \\
\hline 2 & Presentation & 81,66 & Very Good \\
\hline 3 & $\begin{array}{l}\text { The use of web learning in a } \\
\text { flipbook }\end{array}$ & 80,41 & Good \\
\hline 4 & General appearance & 80 & Good \\
\hline 5 & Language / Readability & 80,83 & Good \\
\hline
\end{tabular}

\section{CONCLUSION}

Based on the results of data analysis and discussions that have been carried out, it can be concluded that the results of the validation of material experts, media experts and peers show the products in the excellent category. Then from the first product trial conducted in informatics engineering students obtained an average score of $81 \%$ included in the range $\bar{X}>$ $81.25 \%$ meaning in the good category. The results of the t-test calculations show t-count $>t$-table, where $10.25>2.045$, the use of flipbook gate logic assisted with web learning increases the ability to think logically. And the analysis of N-Gain 0.39 in including medium criteria, then the flipbook gate logic assisted with web learning to increase the ability to think logically effective.

Further research can be developed as follows:

1) Developing more interactive E-learning by involving many interpretations.

2) Looking for influence from the positive and negative impacts of developments in the current digitalization era.

3) Development of software programs for learning.

\section{REFERENCES}

[1] M. A. Bakar and M. Mukhtar, "The Development of a Visual Output Approach for Programming via the Application of Cognitive Load Theory and Constructivism," Int. J. Adv. Comput. Sci. Appl., vol. 10, no. 11, pp. 305-312, 2019.

[2] D. Sugianto, A. G. Abdullah, S. Elvyanti, and Y. Muladi, "Modul Virtual: Multimedia Flipbook Dasar Teknik Digital," Innov. Vocat. Technol. Educ., vol. 9, no. 2, pp. 101-116, 2017.

[3] K. Arai, "Comprehensive e-Learning System with Simulation Capabilities for Understanding of Complex Equations," Int. J. Adv. Comput. Sci. Appl., vol. 10, no. 11, pp. 330-335, 2019.

[4] A. Halim and M. S. Sumbawati, "Pengembangan Media Pembelajaran Berbasis Adobe Air Kompetensi Dasar Gerbang Dasar Rangkaian Logika Di Smk Negeri 2 Bangkalan,” Pendidik. Tek. Elektro, vol. 05, no. 01, pp. 115-122, 2016.

[5] M. H. Ash-Shiddieqy, A. Suparmi, and W. Sunarno, "The effectiveness of module based on guided inquiry method to improve students' logical thinking ability," J. Phys. Conf. Ser., vol. 1006, no. 1, 2018.

[6] G. Deena and D. K. Raja, "Designing an Automated Intelligent eLearning System to Enhance the Knowledge using Machine Learning Techniques," Int. J. Adv. Comput. Sci. Appl., vol. 10, no. 12, pp. 112119, 2019.

[7] S. Issa and A. Zoubi, "E-learning Benchmarking Adoption: A Case Study of Sur University College,” Int. J. Adv. Comput. Sci. Appl., vol. 10, no. 11, pp. 463-470, 2019.

[8] O. Korat, T. Graister, and C. Altman, "Contribution of reading an ebook with a dictionary to word learning: Comparison between kindergarteners with and without SLI," J. Commun. Disord., vol. 79, pp. 90-102, 2019. 
[9] M. S. Hidayatullah, "Pengembangan Media Pembelajaran Berbasis Flip Book Maker Pada Mata Pelajaran Elektronika Dasar Di Smk Negeri 1 Sampang,” J. Pendidik. Tek. Elektro, vol. 05, pp. 83-88, 2016.

[10] D. U. Mulyadi, S. Wahyuni, and S. Wahyuni, "Pengembangan Mediaflash Flipbook Untuk Meningkatkanketerampilan Berfikir Kreatif Siswa Dalam Pembelajaran Ipa Di Smp,” J. Pembelajaran Fis., vol. 4, no. 4, pp. 296-301, 2016.

[11] S. Hayati, A. S. Budi, and E. Handoko, "Pengembangan Media Pembelajaran Flipbook Fisika untuk Meningkatkan Hasil Belajar Peserta Didik," Pros. Semin. Nas. Fis. SNF2015, vol. IV, pp. 49-54, 2015.

[12] J. S. Ab, G. Margono, and W. Rahayu, "The Logical Thinking Ability: Mathematical Disposition and Self-Regulated Learning," J. Phys. Conf. Ser., vol. 1155, no. 1, 2019.

[13] D. Heryadi, "Menumbuhkan karakter akademik academic characters development through logical-based lecturing," J. Pendidik. dan Kebud., vol. 1, no. 3, pp. 317-330, 2016.

[14] S. Suryabrata, "Psikologi Pendidikan," in Psikologi Pendidikan, Jakarta: PT Rajagrafindo Persada, 2012, p. 354.

[15] A. Yani, N. Dewi, and R. Rosita, "Connecting Concepts Test: An Alternative Instrument Form to Improve Students' Logical Thinking Ability in Conceptual Understanding (Case Study on Geography Subject)," IOP Conf. Ser. Earth Environ. Sci., vol. 145, no. 1, 2018.
[16] M. Fadiana, S. M. Amin, A. Lukito, A. Wardhono, and S. Aishah, “Assessment of seventh grade students' capacity of logical thinking," J. Pendidik. IPA Indones., vol. 8, no. 1, pp. 75-80, 2019.

[17] M. Othman, A. F. Rosmani, S. S. M. Fauzi, and U. H. Mazlan, "The Impact of Pair Programming on Students' Logical Thinking: A Case Study on Higher Academic Institution," Soc. Manag. Res., vol. 16, no. June, pp. 85-98, 2019.

[18] A. Agung, B. D. Amin, A. Yani, and A. Swandi, "Pengembangan Bahan Ajar Berbasis E-Learning Mata Kuliah Fisika Dasar pada Jurusan Biologi FMIPA UNM,” Indones. J. Educ. Stud., vol. 21, no. 2, pp. 139147, 2019.

[19] R. N. Prasetyono and E. Trisnawati, "Pengaruh Pembelajaran IPA Berbasis Empat Pilar Pendidikan terhadap Kemampuan Berpikir Kritis," JIPVA (Jurnal Pendidik. IPA Veteran), vol. 2, no. 2, pp. 162-173, 2018.

[20] D. G. H. Divayana, P. W. A. Suyasa, I. P. W. Ariawan, I. W. E. Mahendra, and G. A. D. Sugiharni, "The Design of Digital Book Content for Assessment and Evaluation Courses by Adopting Superitem Concept Based on Kvisoft Flipbook Maker in era of Industry 4.0," J. Phys. Conf. Ser., vol. 1165, no. 1, pp. 0-6, 2019.

[21] M. Barisone et al., "The effectiveness of web-based learning in supporting the development of nursing students' practical skills during clinical placements: A qualitative study," Nurse Educ. Pract., vol. 37, pp. 56-61, 2019. 